This manuscript has been submitted for publication in the special issue Cave Deposits:
Processes, Approaches and Environmental Significance in Frontiers in Earth Science
Quaternary Science, Geomorphology and Paleoenvironment. This pre-print has not
undergone peer-review and subsequent versions of the manuscript may differ from this
version. If accepted, the final version will be available via a DOI link on this page. Please
contact the corresponding author by email with any queries - pennos4@gmail.com Prepared
for EarthArxiv on 24th June 2021. 


\section{Deciphering late Quaternary climatic histories from the Hermes Cave 2 speleothem record, Corinth Rift, Greece}

4 Pennos Ch. ${ }^{1,2}$, Pechlivanidou S. ${ }^{1}$, Modestou S. ${ }^{1,3,4}$, Persoiu A. ${ }^{2,5,6}$, Ninnemann U. ${ }^{1,3}$, Gawthorpe

$5 \quad$ R. ${ }^{1}$, Maccali J. ${ }^{1}$, Lauritzen S-E. ${ }^{1}$, Thuesen $T h .^{1}$

$6 \quad{ }^{1}$ Department of Earth Science, University of Bergen, Bergen, 5020, Norway

7 22 Emil Racoviţă Institute of Speleology, Romanian Academy, Cluj-Napoca, 400006, Romania

$8 \quad{ }^{3}$ Bjerknes Centre for Climate Research, Bergen, 5007, Norway

$9{ }^{4}$ Department of Geography and Environmental Sciences,Northumbria University, Newcastle upon Tyne, NE1 8ST, 10 UK

$11 \quad{ }^{5}$ Stable Isotope Laboratory, Ştefan cel Mare University, Suceava, 720229, Romania

$12 \quad{ }^{6}$ Romanian Institute of Science and Technology, Cluj-Napoca, 400022, Romania

14 Keywords: speleothem, paleoclimate, Late Quaternary, Corinth Gulf, Eastern Mediterrannean

16 Abstract

17 The Greek peninsula is located at the crossroads of several major atmospheric circulation patterns 18 and is consequently characterized by high variability in climatic conditions, making it an important 19 location to examine past climate variability. Over the last decades, the focus of many studies in 20 the region has been to unravel Holocene paleoclimatic oscillations and their impact on the 21 development of ancient civilizations using terrestrial archives and especially speleothem records. 
22 In this study we contribute to the regional climate record over the Quaternary using a speleothem

23 from the Hermes Cave located at the southern flanks of the Corinth Rift in central Greece. Our

24 stalagmite grew over two distinct periods, from 127 to $105 \mathrm{ka}$ and from 18 to 8 ka B.P. separated

25 by a distinct hiatus. We have examined its growth history, stable isotope geochemistry and

26 elemental composition. Higher growth rates are observed during the Eemian and the early

27 Holocene and are attributed to high water recharge implying humid conditions. A gradual isotopic

28 enrichment before the growth hiatus of the stalagmite suggests a gradual drying that can be related

29 to glacier advance. Our record correlates with other paleoclimate records from the broader area

30 confirming and extending a pattern of coherent changes in paleoclimate across the Eastern

31 Mediterranean basin.

\section{Introduction}

34 Climate in the Mediterranean Basin (MB) is a complex result of the conjunction of several 35 atmospheric systems: westerlies from the North Atlantic Ocean, subtropical high-pressure systems 36 originating over North Africa's arid zones, the Siberian High pressure system (SH), the North 37 Atlantic Oscillation (NAO) (Lionello et al. 2006 ; Xoplaki et al., 2000 ) and the African and Asian 38 Monsoons (Lionello and Galati, 2008). North Atlantic Oscillation in particular strongly impacts 39 winter atmospheric circulation patterns in the MB, with subsequent effects on river runoff (e.g. 40 Tsimplis et al., 2006: Zerefos et al, 2011). Examining climatic patterns over the past 500 years, 41 Luterbacher et al. (2006) concluded that a negative NAO index is related to wet and cool conditions 42 in the MB, while a positive NAO index is associated with strong westerlies at high and mid 43 latitudes, and dry and warm conditions in the MB. 
44 However, the interplay of the atmospheric systems does not have the same intensity across the

45 whole length of the MB. For example Luterbacher and Xoplaki (2003) suggest that there is a clear 46 differentiation between the Eastern Mediterranean basin (EMB) and the Western and Central

47 Mediterranean. Winter air temperature in the Eastern part appears to be negatively correlated with the NAO index, in contrast to the Western and Central part where there seems to be a small positive 49 correlation (Zerefos et al., 2011).

Climate research continues in the MB, utilizing many different archives from the area. Many are

51 based on marine bio-proxies, and aim to understand the paleoceanographic evolution in the EMB

52 and the prevailing paleoclimatic conditions driving that evolution (e.g. Triantaphyllou et al., 2009;

53 Koukousioura et al., 2012; Kouli et al., 2012; Rohling et al., 2015; Triantaphyllou et al., 2015;

54 Gogou et al., 2016; Rohling et al., 2019). Terrestrial records can also provide insight, in some

55 cases more directly, on the paleoclimatic evolution of the area. Existing records are many and

56 diverse, including pollen studies (e.g. (Tzedakis et al., 2002; Tzedakis et al., 2006; Tzedakis, 2010;

57 Jones et al., 2012; Milner et al., 2013), speleothems (e.g. Bar-Matthews et al., 2000; Fleitmann et 58 al., 2009; Psomiadis et al., 2009; Finné et al., 2014; Finné et al., 2015; Nehme et al., 2015; Nehme 59 et al., 2018; Psomiadis et al., 2018; Regattieri et al., 2018; Peckover et al., 2019; Regattieri et al., 60 2020), geomorphic indexes (e.g. Styllas et al., 2018; Leontaritis et al., 2020) and clastic 61 sedimentary sequences (e.g. Lespez et al., 2017; Styllas and Ghilardi, 2017; Katrantsiotis et al., 62 2019; McNeill et al., 2019; Pennos et al., 2021). Despite this plethora of publications, most of the 63 studied records do not present a continuous temporal extent for the late Quaternary and/or focus 64 mainly on the time span that ancient civilizations flourished.

Here we aim to investigate the paleoclimatic evolution of the area from a stalagmite collected from 
67 Holocene. We compare our results with other speleothem records from the area to understand 68 regional scale climate dynamics, and to compliment the findings of the recent IODP Expedition 69381 (McNeill et al., 2019) to decipher climate forcings affecting fluvial sediment fluxes in the Gulf 70 of Corinth.

71

72 2. Setting

73 Hermes cave (HC) is located on Kyllini mountain at $1614 \mathrm{~m}$ a.m.s.l. close to Ziria ski resort in the

74 Peloponnese peninsula in southern Greece (Fig.1). It is named after the ancient god Hermes, who, 75 according to Greek mythology, was born and raised inside the cave. The cave entrance is located 76 on a cliff facing towards Flabouritsa valley and the Gulf of Corinth. The cave has been known 77 since antiquity, and has been visited by numerous people throughout the years who caused 78 extensive damage to the speleothems. 

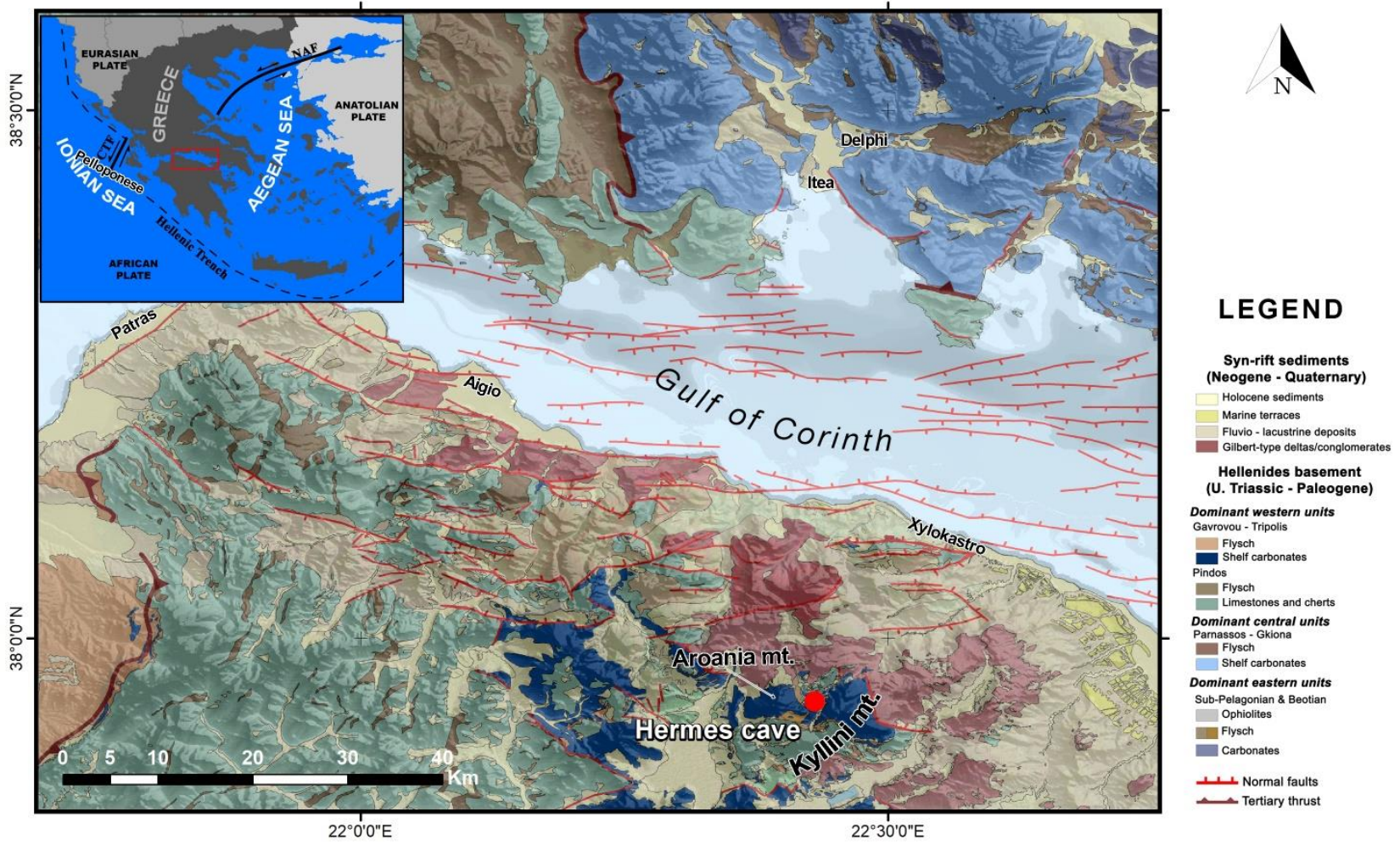

Figure 1. Regional geological map modified from Skourtsos et al. (2017).

It formed in upper Triassic-Paleogene limestones belonging to the Gavrovo-Tripoli geotectonic

83 zone of the Hellenides orogenic belt ( e.g. Skourtsos et al.,2017; Gawthorpe et al., 2018). These

84 carbonates outcrop on the southern flank of the Corinth extensional rift, and have undergone brittle

85 deformation and are densely fractured. The extensive fracturing allowed surface water to penetrate

86 into the limestone and initiate cave formation. Hermes Cave is elongated in a NE-SW direction

87 and the cave floor dips steeply, $>45^{\circ}$, toward the SW, following the bedding of the limestones.

88 Speleothem formations are extensive, with stalagmites intercepting rock debris and forming small

89 terraces in some places. 
90 The modern climate in the broader area corresponds to "Mediterranean Climate" with $9.7^{\circ} \mathrm{C}$ mean

91 annual temperature and $1296 \mathrm{~mm}$ mean annual precipitation (Mamara et al., 2017). The climate is

92 characterized by mild and wet winters (December - March) that contribute most of the annual

93 precipitation, with dry, warm summers where occasional convective precipitation occurs, resulting

94 in strong, stormy rainfall events (Xoplaki et al., 2000; Feidas et al., 2007). Xoplaki et al. (2004)

95 concluded that although there is large spatio-temporal variability in the region's winter

96 precipitation, a significant portion (30\%) is explained by large-scale atmospheric circulation. This

97 pattern is clearly observed when winter NAO-driven depressions move north east from the North

98 Atlantic through the Gibraltar straits and release rainfall on western Greece (Styllas et al., 2015

99 and references therein).

3. Methods

\section{$102 \quad 3.1$ Speleothem sampling}

103 In order to collect a stalagmite that is active throughout the year and records both winter and 104 summer precipitation, we visited the cave during the dry season (late August). We collected an 105 active stalagmite (ZCG1) in situ from a relatively small chamber far from the entrance (Fig.2), 106 where no air draft was evident, to exclude any drip water evaporation. The sampling chamber is a 107 small blind passage, $6 \mathrm{~m}$ long, $2.5 \mathrm{~m}$ high and $4 \mathrm{~m}$ wide, that dips steeply towards the main 108 development axis of the cave. It is located $50 \mathrm{~m}$ from the entrance and ca $60 \mathrm{~m}$ below the surface. 109 The $30 \mathrm{~cm}$ tall stalagmite was extracted from the cave and was later cut in half along the growth 110 axis. One part of the stalagmite was stored for reference, and from the other half a $2 \mathrm{~cm}$ thick slab 111 was extracted. From macroscopic observation it is evident that ZCG1 is a densely laminated 
112 stalagmite. Most of the laminae are opaque, with no visible signs of diagenesis of the calcite fabric

113 (Fig. 3).

114

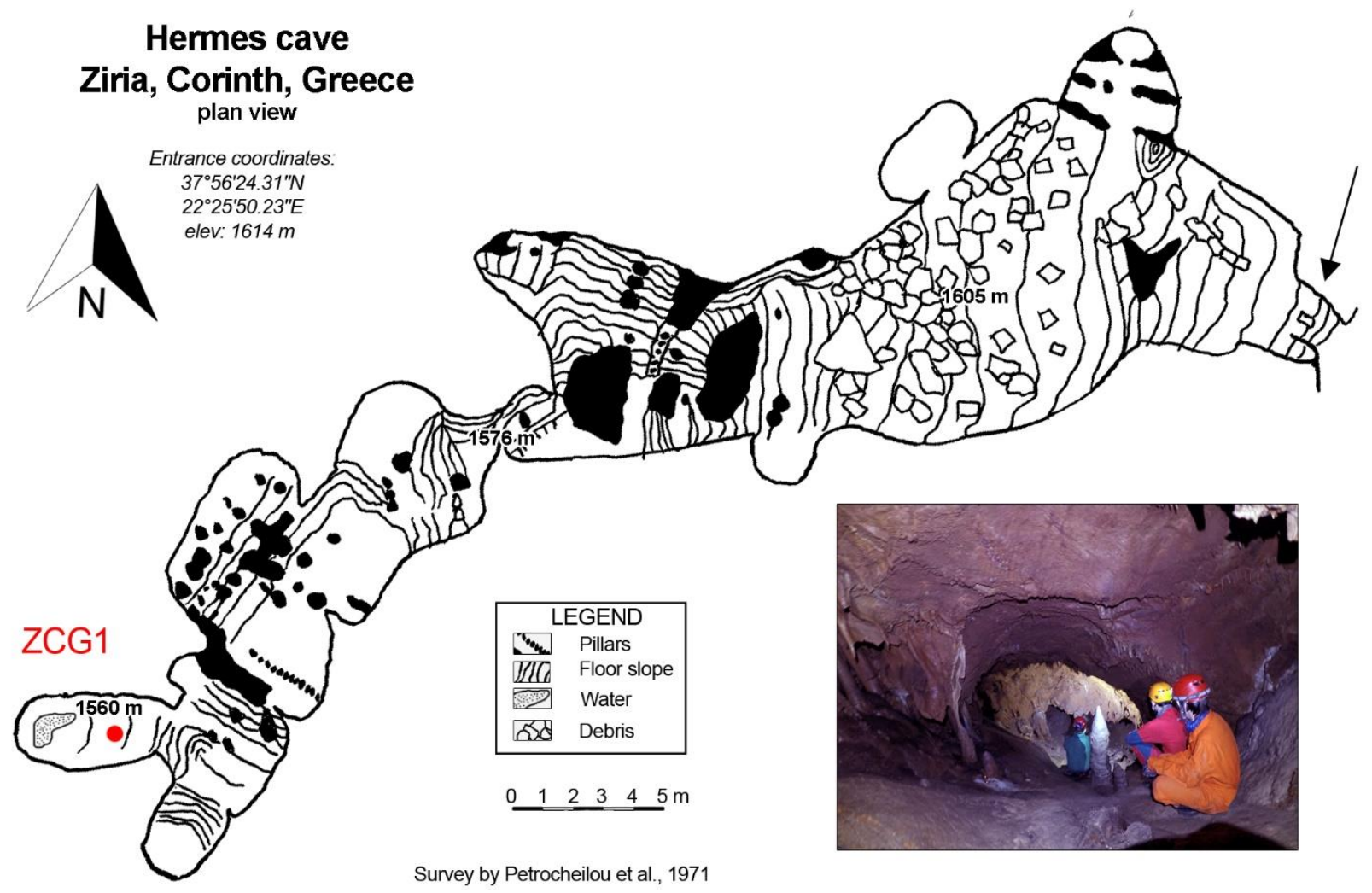

Figure 2. Plan view of Hermes Cave from Petrocheilou (1972). Red dot shows the position of the stalagmite. Inset photograph shows the chamber where stalagmite ZCG1 was formed. 


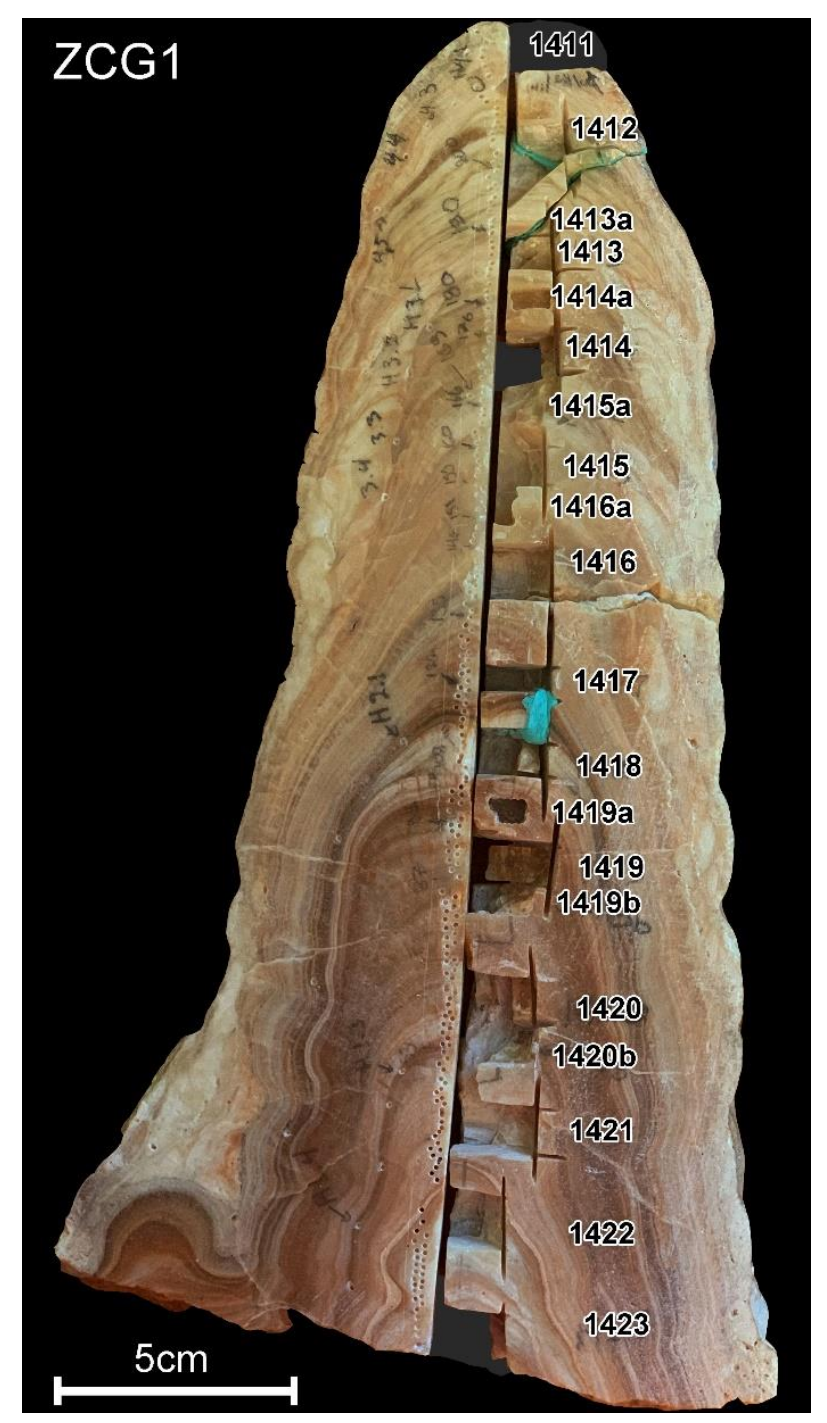

117 Figure 3. Polished section of the ZCG1 stalagmite. Small pits indicate stable isotope sampling 118 position. Rectangular trenches indicate the position of the Th/U samples with their corresponding lab id.

\subsection{Th/U dating}

122 To construct the age-depth model, we extracted seventeen samples along the growth axis either by 123 drilling or milling. Samples were first heated at $650^{\circ} \mathrm{C}$ for 4 hours to remove organic material. 
124 Chemical separation of $U$ and Th was adapted from Edwards (1988). The samples were spiked 125 with a mixed ${ }^{233} \mathrm{U}_{-}{ }^{236} \mathrm{U}^{229} \mathrm{Th}$ solution (calibrated against Harwell Uraninite (HU-1) solution 126 considered at secular equilibrium) and dissolved in concentrated $\mathrm{HNO}_{3}$. Column chemistry 127 cleaned Fe solution was added, and Fe precipitates were formed by dropwise addition of $\mathrm{NH}_{4} \mathrm{OH}$. 128 Fe precipitates were rinsed with $18.2 \mathrm{M} \Omega$ deionized water, re-dissolved with $6 \mathrm{M} \mathrm{HCl}$ and loaded 129 onto AG1X8 resin for U-Th separation. Uranium and Th were further purified through consecutive 130 passes onto U/TEVA and AG1X8 resins, respectively. Th and $\mathrm{U}$ isotopes were analyzed on a $\mathrm{Nu}$

131 Plasma II MC-ICP-MS. Mass bias was corrected by standard-sample bracketing using HU-1 132 solution. Blank concentrations were ${ }^{238} \mathrm{U}<0.2 \mathrm{ng} ;{ }^{234} \mathrm{U}<30 \mathrm{fg} ;{ }^{232} \mathrm{Th}<11 \mathrm{pg} ;{ }^{230} \mathrm{Th}$ was below 133 the detection limit. Activity ratios were calculated using decay constant values from Bourdon et 134 al. (2003). Ages were calculated using Isoplot 3.75 (Ludwig, 2003) without decay constant 135 uncertainties. Long term analytical reproducibility of the HU-1 solution $(n=28$, measured over 13615 months $)$ is $\operatorname{AR}\left({ }^{234} \mathrm{U} /{ }^{238} \mathrm{U}\right) 1.002+/-0.001$ and $\mathrm{AR}\left({ }^{230} \mathrm{Th} /{ }^{238} \mathrm{U}\right) 1.003+/-0.002(2 \mathrm{SD})$. All U137 series data reported in tables are presented with $\pm 2 \sigma$ uncertainty, propagated to include analytical 138 and spike calibration uncertainties, unless otherwise indicated.

\subsection{Stable isotopes}

141 Stable isotope sampling was performed by milling with a $0.7 \mathrm{~mm}$ diameter bit along the growth 142 axis, with $1 \mathrm{~mm}$ step, resulting in a total of 218 samples. $\delta^{18} \mathrm{O}$ and $\delta^{13} \mathrm{C}$ analyses were conducted 143 at the University of Bergen (FARLAB) using a MAT 253 mass spectrometer coupled to an 144 automated Kiel IV preparation device. Approximately $50( \pm 20) \mu \mathrm{g}$ of sample powder was reacted 145 with concentrated ortho-phosphoric acid $\left(\mathrm{H}_{3} \mathrm{PO}_{4}\right)$ at a constant $70{ }^{\circ} \mathrm{C}$. Isotope values are reported 146 on the Vienna Pee Dee Belemnite (VPDB) scale calibrated using the scale reference standard NBS 
14719 (value $1.95 \%$ and $2.2 \%$ for $\delta^{13} \mathrm{C}$ and $\delta^{18} \mathrm{O}$, respectively) together with NBS $18(-5.01 \%$ and $148 \quad 23.2 \%$ for $\delta^{13} \mathrm{C}$ and $\delta^{18} \mathrm{O}$, respectively ; Friendman et al., 1982; Hut, 1987; Stiltcher, 1993; Coplen 149 et al., 2006 refs). Analytical reproducibility (1s), based on replicate measurements of the in-house 150 carrara marble standard CM12 spanning the same mass range and run over the analysis period $151(\mathrm{n}=128)$ was 0.06 and $0.03 \delta^{18} \mathrm{O}$ and $\delta^{13} \mathrm{C}$, respectively. Finally, we performed Hendy's tests 152 (Hendy, 1971) within 4 distinct laminae as a first check for correlation between $\delta^{18} \mathrm{O}$ and $\delta^{13} \mathrm{C}$, 153 providing information about possible kinetic effects during precipitation.

$154 \quad 3.4 \mu-X R F$

155 Relative elemental composition was determined by x-ray fluorescence using an Itrax core scanner.

156 Core scanning was conducted on the $2 \mathrm{~cm}$ thick stalagmite slab, along the growth axis at $1 \mathrm{~mm}$ 157 intervals using a Mo x-ray tube (Croudace et al., 2006). Exposure time was 10 s, power supply 158 was $30 \mathrm{kV} / 55 \mathrm{~mA}$. The output was later processed using Q-spec software. Following the calcite 159 growth modelling approach of Wong et al. (2011), we interpret high Sr/Ca values as representing 160 summer season speleothem growth and low values as winter growth, respectively.

\section{Results}

\subsection{Age Model and growth rate}

The Th/U analysis produced ages ranging from $7.0 \pm 4.2 \mathrm{ka}$ to $127.9 \pm 52.5 \mathrm{ka} \mathrm{B.P.} \mathrm{(Table} 1)$. To generate a growth model we used the Mod-Age software (Hercman and Pawlak, 2012) that employs a weighted scatterplot smoothing (LOESS) interpolation to build the chronological model. Three $\mathrm{Th} / \mathrm{U}$ dates were indicated by the software to be outliers (see fig $4 \mathrm{~b}$ ) and were not 
169 a hiatus in growth at ca $135 \mathrm{~mm}$ from the base. This hiatus extends between approximately 105 to

171 Table 1. Activity ratios and age calculations from ZCG1 stalagmite.

\begin{tabular}{|c|c|c|}
\hline Sample ID & Depth $(\mathrm{mm})$ & $238 \mathrm{U} \mu \mathrm{g} / \mathrm{s}$ \\
\hline 1411 & 0.85 & 22 \\
\hline 1412 & 2.6 & \\
\hline $1413 a^{*}$ & 3.6 & 19 \\
\hline 1413 & 5.1 & \\
\hline $1414 a^{*}$ & 6.15 & \\
\hline 1414 & 7.2 & \\
\hline $1415 a^{*}$ & 8.25 & 22 \\
\hline 1415 & 9.7 & 18 \\
\hline $1416 a^{*}$ & 10.5 & \\
\hline 1416 & 11.95 & 1 \\
\hline 1417 & 14.15 & 16 \\
\hline 1418 & 15.65 & \\
\hline $1419 a^{*}$ & 16.85 & 11 \\
\hline 1419 & 17.95 & 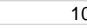 \\
\hline $1419 b^{*}$ & 18.7 & 12 \\
\hline $1420 b^{*}$ & 21.75 & \\
\hline 1423 & 27.85 & \\
\hline
\end{tabular}

2oe

\begin{tabular}{|c|}
\hline $\begin{array}{r}230 \mathrm{Th} / \mathbf{2 3 8 U}) \\
0.0683\end{array}$ \\
\hline $\begin{array}{l}0.0683 \\
0.0727\end{array}$ \\
\hline 0.0818 \\
\hline 0.0841 \\
\hline 0.0866 \\
\hline 0.0789 \\
\hline 0.2021 \\
\hline 0.0795 \\
\hline 0.0702 \\
\hline 0.1033 \\
\hline 0.2129 \\
\hline 0.7299 \\
\hline 0.7040 \\
\hline 0.7381 \\
\hline 0.7063 \\
\hline $\begin{array}{l}0.7541 \\
0.7381\end{array}$ \\
\hline
\end{tabular}

\begin{tabular}{|r|r|}
\hline 2oe & (234U/238U) \\
\hline 0.0338 & 1.078 \\
\hline 0.0451 & 1.099 \\
\hline 0.0005 & 1.079 \\
\hline 0.0352 & 1.103 \\
\hline 0.0004 & 1.109 \\
\hline 0.0222 & 1.095 \\
\hline 0.0012 & 1.095 \\
\hline 0.0447 & 1.109 \\
\hline 0.0004 & 1.112 \\
\hline 0.0431 & 1.123 \\
\hline 0.0688 & 1.125 \\
\hline 0.1407 & 1.154 \\
\hline 0.0040 & 1.125 \\
\hline 0.1202 & 1.101 \\
\hline 0.0045 & 1.112 \\
\hline 0.0043 & 1.140 \\
\hline 0.0879 & 1.057 \\
\hline
\end{tabular}

\begin{tabular}{|c|c|}
\hline $2 \sigma e$ & Age uncr (k \\
\hline 0.074 & \\
\hline 0.093 & 7 \\
\hline 0.006 & \\
\hline 0.078 & \\
\hline 0.005 & \\
\hline 0.064 & \\
\hline 0.006 & 22. \\
\hline 0.078 & \\
\hline 0.006 & \\
\hline 0.094 & \\
\hline 0.118 & 22 \\
\hline 0.183 & 105. \\
\hline 0.007 & 104. \\
\hline 0.096 & 117 \\
\hline 0.007 & 107 \\
\hline 0.006 & 114 \\
\hline 0.067 & 128. \\
\hline
\end{tabular}

\begin{tabular}{|r|r|} 
2oe & (232Th/238U) \\
\hline 4.2 & 0.0040 \\
\hline 5.5 & 0.0053 \\
\hline 0.1 & 0.0042 \\
\hline 4.4 & 0.0078 \\
\hline 0.1 & 0.0037 \\
\hline 2.9 & 0.0056 \\
\hline 0.2 & 0.0172 \\
\hline 5.4 & 0.0040 \\
\hline 0.1 & 0.0023 \\
\hline 5.6 & 0.0190 \\
\hline 11.2 & 0.0915 \\
\hline 97.0 & 0.0813 \\
\hline 1.5 & 0.0694 \\
\hline 65.8 & 0.1053 \\
\hline 1.7 & 0.0505 \\
\hline .7 & 0.0972 \\
\hline 52.5 & 0.0151 \\
\hline
\end{tabular}

\begin{tabular}{|r|r|}
\hline 26e & 230Th/232T \\
\hline 0.0020 & 17.2 \\
\hline 0.0033 & 13.7 \\
\hline 0.0003 & 19.6 \\
\hline 0.0034 & 10.8 \\
\hline 0.0003 & 23. \\
\hline 0.0017 & 14. \\
\hline 0.0035 & 11. \\
\hline 0.0023 & 20. \\
\hline 0.0002 & 30.4 \\
\hline 0.0084 & 5.4 \\
\hline 0.0392 & 2.3 \\
\hline 0.0723 & 9.0 \\
\hline 0.0492 & 10. \\
\hline 0.0924 & 7.0 \\
\hline 0.0359 & 14.0 \\
\hline 0.0737 & 7.8 \\
\hline 0.0126 & 48.7 \\
\hline
\end{tabular}

\begin{tabular}{|c|c|c|c|}
\hline 32Th & $2 \sigma e$ & Age cr (ka) & $2 \sigma e(k a)$ \\
\hline 17.2 & 8.5 & 7.0 & 4.2 \\
\hline 13.7 & 8.5 & 7.3 & 5.5 \\
\hline 19.6 & 0.1 & 8.5 & 0.3 \\
\hline 10.8 & 4.5 & 8.4 & 4.4 \\
\hline 23.1 & 0.1 & 8.7 & 0.3 \\
\hline 14.1 & 4.0 & 8.0 & 2.9 \\
\hline 11.7 & 0.1 & 21.9 & 0.6 \\
\hline 20.1 & 11.3 & 8.0 & 5.4 \\
\hline 30.4 & 0.2 & 7.0 & 0.2 \\
\hline 5.4 & 2.3 & 10.0 & 5.5 \\
\hline 2.3 & 0.8 & 20.4 & 11.0 \\
\hline 9.0 & 1.6 & 103.6 & 96.6 \\
\hline 10.1 & 0.1 & 102.8 & 5.8 \\
\hline 7.0 & 1.3 & 115.1 & 65.6 \\
\hline 4.0 & 0.1 & 107.9 & 5.0 \\
\hline 7.8 & 0.0 & 114.1 & 5.4 \\
\hline 48.7 & 5.9 & 127.9 & 52.5 \\
\hline
\end{tabular}

173

174
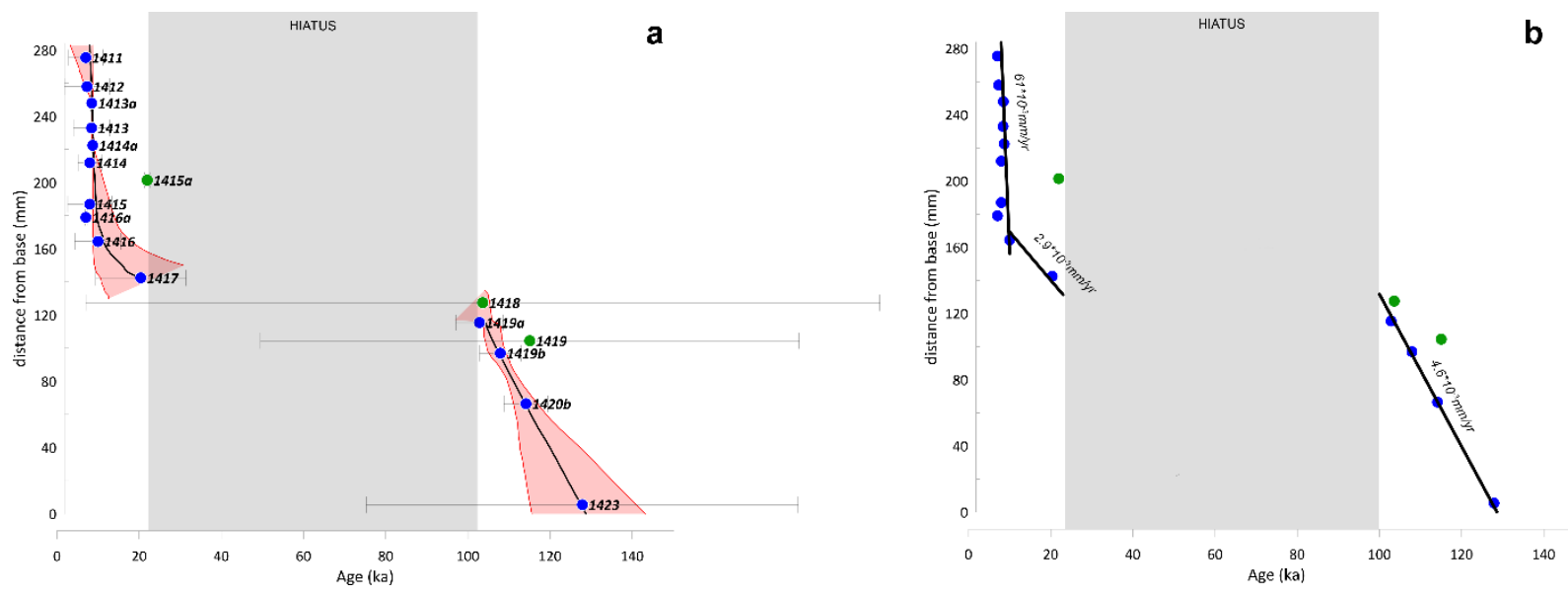

Figure 4. a) Age depth model. Blue dots are dating results, horizontal error bars are $2 \sigma$. Red shading illustrates the $2 \sigma$ uncertainy of the age model. Outliers are shown in green. b) Growth rates of the stalgmite indicated per major intervals. different linear regression lines with high coefficient $\left(\mathrm{R}^{2}>0.85\right)$ were generated (Fig.4b). The 
181 oldest part of the stalagmite developed between $127.9 \mathrm{ka}$ to ca $105 \mathrm{ka}$ B.P. at a rate of $4.6 \times 10^{-3}$

$182 \mathrm{~mm} / \mathrm{yr}$. Following the growth hiatus the rate between $20.4 \mathrm{ka}$ to $10 \mathrm{ka}$ B.P was lower at $2.9 \times 10^{-3}$

$183 \mathrm{~mm} / \mathrm{yr}$. but the youngest part of the stalagmite, $10 \mathrm{ka}$ to $7 \mathrm{ka} \mathrm{B.P.,} \mathrm{formed} \mathrm{at} \mathrm{a} \mathrm{much} \mathrm{higher} \mathrm{growth}$

184 rate of $6.1 \times 10^{-3} \mathrm{~mm} / \mathrm{yr}$ (Fig.4b).

185 The age estimate for the oldest sample (1423, Table 1, Fig. 3) has relatively poor precision. This 186 age estimate is critical for constraining the age model as it lies at an end point, thus the 187 measurement was repeated with a new portion of stalagmite material. Unfortunately, the result of 188 this repeat measurement were not improved over the original, likely due to detrital contamination. 189 To compensate for the resulting age model uncertainty on ages older than $\sim 115 \mathrm{ka}$, we compare 190 the stable isotope results grouped over the Last Interglacial (116 - $129 \mathrm{ka}$; Tzedakis et al., 2018) 191 and Holocene (to $\sim 12.5 \mathrm{ka}$; Styllas et al., 2018) according to the median age model dates, and 192 compare to the same data but given ages at the maximum and minimum values of the age model 193 error envelope (see discussion).

\section{$4.2 \delta^{18} \mathrm{O}$ and $\delta^{13} \mathrm{C}$ record}

196 The results from the Hendy tests (Hendy, 1971) suggest isotopic equilibrium conditions during the 197 majority of ZCG1 deposition (see suplementary). It is evident that the variations of $\delta^{18} \mathrm{O}$ and $\delta^{13} \mathrm{C}$ 198 show no positive correlation along each of the tested layer, and there is no enrichment in ${ }^{18} \mathrm{O}$ 199 towards the external part of the stalagmite. The exception to this is near the termination of growth 200 before the hiatus, which is marked by an isotopic enrichment (Fig. 5) that might be indicative of 201 kinetic effects, possibly due to a change in climatic conditions. 
$202 \delta^{18} \mathrm{O}$ values range from -8.8 to $-6.2 \%$ (Fig. 5). For the first $10 \mathrm{ka}$ of stalagmite development the 203 values show minor variations from -7.7 to $-6.7 \%$ until ca $123 \mathrm{ka} \mathrm{B.P.} \mathrm{This} \mathrm{period} \mathrm{is} \mathrm{followed} \mathrm{by}$ 204 a period of lower values (down to $-8.7 \%$ ) lasting for almost $3000 \mathrm{yrs}$. An increase in $\delta^{18} \mathrm{O}$ values 205 follows, which peaks at 118 ka B.P (maxima -6.8 \%o). This period is trailed by a decrease of $\delta^{18} \mathrm{O}$ 206 values until ca 115 ka B.P. where the values osciliate between -7.9 and -7.3 \%o up until $112 \mathrm{ka}$ 207 B.P. From 106 ka B.P. to ca105 ka B.P. when the growth of the stalagmite is halted, $\delta 180$ values 208 grow again (maxima $-6.2 \%$ ) but, as stated above, this might be indicative of kinetic effects thus 209 will not be interpreted in terms of climate.

210 At ca $20 \mathrm{ka}$ B.P. the stalagmite resume growth and the $\delta 180$ exhibits a slight increase, from -8.3 211 to $-7.9 \%$, for the succeeding $3.5 \mathrm{ka}$. This period is followed by an abrupt decrease in $\delta 180$ to $2128.5 \%$, followed by an interval of minor osciliations (between -8.5 to $-8 \%$ ) until ca 11 ka B.P. 213 Low values of $\delta^{18} \mathrm{O}$ are recorded during the next growth interval until ca $10.7 \pm 3.5 \mathrm{ka}$ B.P., 214 followed by a general increase in $\delta 18 \mathrm{O}$ to $-7.4 \%$ that peaks at ca $8.5 \mathrm{ka}$ B.P. This increase of the $215 \delta^{18} \mathrm{O}$ values is interrupted by two prominent negative peaks at $9.5 \pm 3$ and $9.1 \pm 3$ ka B.P. $\left(\delta^{18} \mathrm{O}\right.$ 216 values -8.72 and $-8.7 \%$ respectively). Finaly, at the youngest part of the stalagmite after a sharp 217 decrease, $\delta^{18} \mathrm{O}$ values oscilliate from -8.4 to $-7.8 \%$ when the stalagmite growth halts at ca $8 \mathrm{ka}$ 218 B.P.

$219 \delta^{13} \mathrm{C}$ values range between -10.4 to $-3.5 \%$ VPDB (Fig.5). From 126 ka to 115 ka B.P., $\delta^{13} \mathrm{C}$ show 220 slight variations from -8.7 to $-8.2 \%$. After a short and sharp ${ }^{13} \mathrm{C}$ enrichment at 113 ka B.P., a 221 period of ca 4 millenia with minor osciliations in $\delta^{13} \mathrm{C}$ values follows. During the next evolutionary 222 stage of the stalagmite, a strong increase in $\delta^{13} \mathrm{C}$, around $-3.7 \%$, , and lasts for ca 2 millenia. 223 Different growth conditions, starting at A new period begings with a sharp decrease of $\delta^{13} \mathrm{C}$ at ca $224111 \mathrm{ka} \mathrm{BP}$, continuing with slight variations overprinted on this long term ${ }^{13} \mathrm{C}$-depletion until the 
225 stalagmite growth is interrupted at ca $105 \mathrm{ka} \mathrm{B.P.} \mathrm{Past} \mathrm{the} \mathrm{growth} \mathrm{hiatus,} \mathrm{the} \delta^{13} \mathrm{C}$ record presents 226 a slight increase for the succeeding $3.5 \mathrm{ka}$ from -7.5 to $-6.5 \%$ o. From 15.9 to $11.2 \mathrm{ka}$ B.P., $\delta^{13} \mathrm{C}$ 227 decreases from -7.6 to $-9.7 \%$. At the youngest part of the stalagmite the $\delta 13 \mathrm{C}$ values are 228 marginally decreasing, with minor flactuations on the general trend interrupted by four prominent 229 peaks at $10.5,10,8.9$ and $8.4 \mathrm{ka} \mathrm{B.P.}$

$231 \quad 4.3 \mu$-XRF

232 The XRF measurements generated a detailed trace element profile of the stalagmite. The X-ray 233 fluoresence signal in such dense material as speleothems is strong; consequently, the scan returned 234 good counting results for numerous elements (e.g. Al, Si, P, Sr, Ti, Fe). Here we focus mainly on 235 the Sr/Ca ratio since it can be used as paleoclimate proxy (e.g. (Kluge et al.; Fairchild and Treble, 236 2009; Wong et al., 2011; Fairchild and Baker, 2012). Six distinct intervals exhibit an excess in Sr 237 compared to $\mathrm{Ca}$ at 122, 120-117, 114, 113, 108-106.5. and ca 105 to 104 ka B.P. (Fig.5). After the 238 depositional hiatus and up until $11 \mathrm{ka} \mathrm{BP}$, The Sr/Ca ratios shows minor fluctuations. From $11 \mathrm{ka}$ 239 until ca $9.8 \mathrm{ka}$ B.P. there are two intervals where again an excess in Sr is observed (at 11 and 9.8 240 respectively). From $9.8 \mathrm{ka}$ B.P. until the end of the record there is general increase on in the $\mathrm{Sr} / \mathrm{Ca}$ 241 ratio with four peaks at 9.5, 9.1, 8.5 and 8.1 ka B.P. 


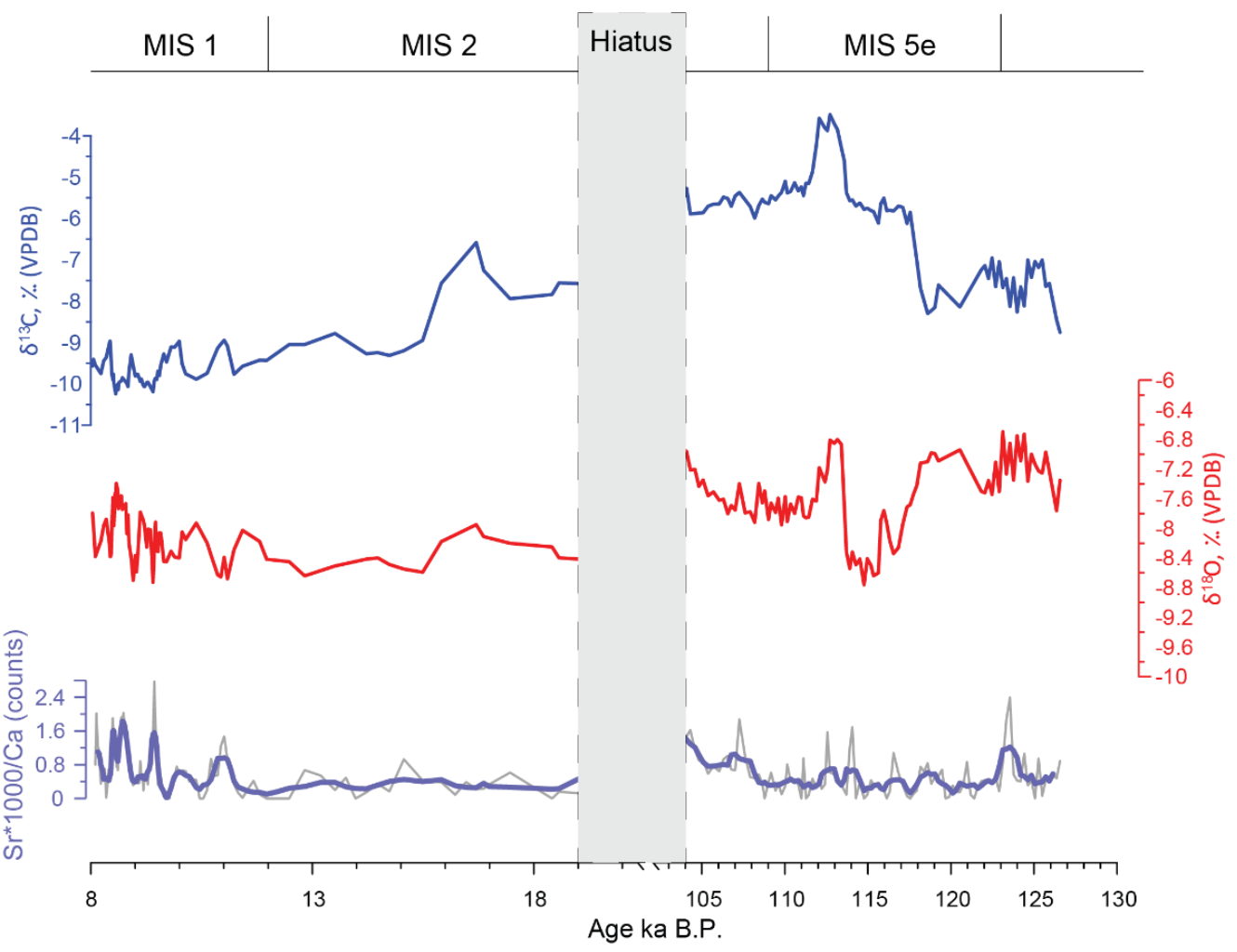

Figure 5. Carbon isotope (blue line), oxygen isotope (red line) and Sr/Ca $\mu$-XRF (black and purple lines) profiles along ZCG1 stalagmite.

\section{Discussion}

\section{$248 \quad 5.1$ Major climate patterns}

249 The ZCG1 stalagmite formation started at around 127 ka indicating the establishment of climatic

250 conditions that favored the speleothem deposition in this karstic setting. This period correlates

251 with the beginning of the maximum interglacial conditions that enabled high growth rates recorded

252 in stalagmites across Europe (Drysdale et al., 2009; Genty et al., 2013; Demeny et al., 2017). The

253 carbon isotope signal from the ZCG1 stalagmite reflects soil activity, which itself is dependent on

254 temperature and precipitation regime (e.g. Genty et al., 2001) while the oxygen isotope 
255 compositions reflect the combined effect of temperature and moisture source (e.g. Dansgaard, 256 1964; McDemortt, 2004; Nehme et al.,2015 and references within).

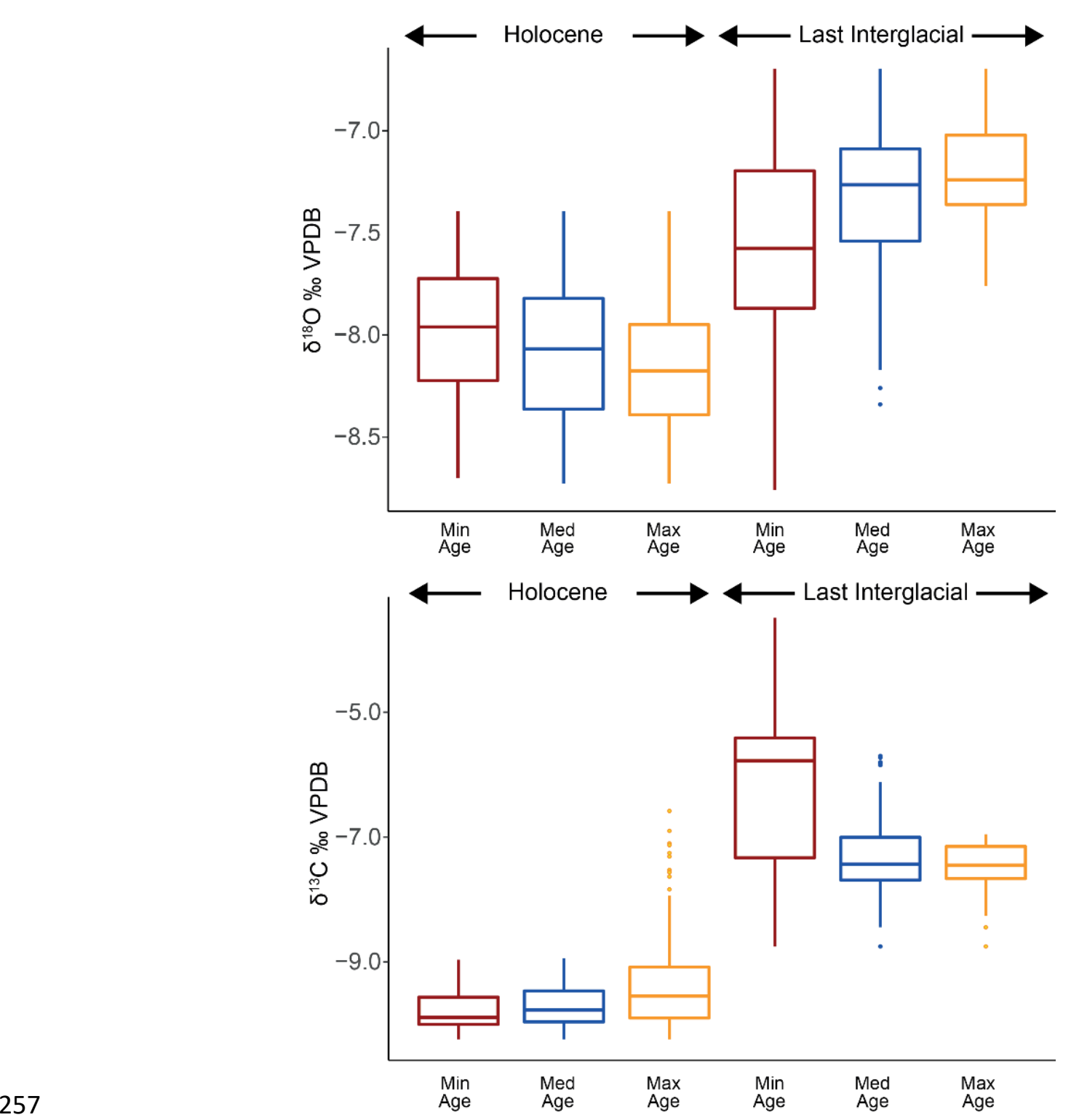

258 Figure 6. Box plots comparing Ziria speleothem stable isotope compositions from the Holocene

259 (to $11.7 \mathrm{ka}$ ) against the Last Interglacial (127 to $116 \mathrm{ka}$ ) by possible ages (med age = median 260 age min age $=$ minimum age at error envelope limit $;$ max age $=$ maximum age at error envelope limit). 
263 Figure 6 compares the stable isotope data from the Holocene (to $11.7 \mathrm{ka}$ ) with those from the Last

264 Interglacial (116 to $127 \mathrm{ka}$ ), with the data grouped based on different options in the age model

265 (median age, minimum age according to the error envelope, maximum age according to the error

266 envelope). The purpose of this comparison is to examine how the relationship between the overall

267 speleothem isotope composition for each period changes with age. With the exception of $\delta^{18} \mathrm{O}$

268 compositions using minimum age values, all versions of the data are significantly different and

269 show similar differences in isotopic composition. This indicates that, at minimum, the different

270 age possibilities for the oldest part of Ziria stalagmite do not affect broad interpretations of climate

271 for the Last Interglacial period, where the age model has the largest uncertainty. Concurrenly, this

272 shows a higher climatic variability during the Last Interglacial compared to the Holocene as was

273 previously shown by Tzedakis et al. (2018)

274 Alongside the onset of stalagmite growth, $\delta^{13} \mathrm{C}$ values are increasing and the $\delta^{18} \mathrm{O}$ values 275 decreasing (Fig. 7), suggesting that at the beginning of the interglacial cycle the climate was colder 276 and drier in the region and had not yet reached stable interglacial conditions (Tzedakis.et al., 2018).

277 Following this period of instability and up to $117 \mathrm{ka}, \delta^{13} \mathrm{C}$ values exhibit two minima (at 122 and

278117 ka respectively) suggesting high soil activity that can be attributed to forest expansion due to 279 humid conditions that correlate broadly with the growth of near sea level microbial brackish water 280 bioherms $(\sim 116 \mathrm{ka})$ at the Perachora pennnsula, eastern part of the Gulf of Corinth (Portman et al., 281 2005) due to high influx of fresh water whereas the period between these two excursions exhibits 282 high values that corresponds to a dryer period for the broader area. This is in contrast to Central 283 Europe stalagmite records (e.g., Baradla cave; Demeny et al., 2017; Fig. 7) which indicate this 284 period is considered the optimum within the interglacial (Govin et al., 2015) with high soil activity. 
285 The $\delta^{18} \mathrm{O}$ record for the same period exhibits low variation suggesting no major changes in the 286 source or amount of precipitation. The $\delta^{18} \mathrm{O}$ values reach a minimum at $115 \mathrm{ka}$, while concurrently 287 the $\delta^{13} \mathrm{C}$ values increase, pointing to low soil productivity and establishment of cold and dry 288 conditions in the area towards the onset of the glacial period. The same trend for both $\delta^{13} \mathrm{C}$ and $289 \delta^{18} \mathrm{O}$ values continues until circa $112 \mathrm{ka}$ with an interruption towards $114 \mathrm{ka}$ where the oxygen 290 record exhibits a positive peak and the carbon record a negative peak. We suggest that these 291 changes in the overall trend can be attributed to a period where cyclonic depressions forming over 292 Africa are controlling the climate probably the same ones responsible for the transport of Saharan 293 dust to the area (e.g. Stuut et al., 2009; Philandras et al., 2011; Remoundaki et al., 2011). The 294 reduction in soil activity during this period is most likely related to a change in vegetation, similar 295 to that which occurred in the Balkan peninsula when low vegetation replaced thick interglacial 296 forests (Tzedakis et al., 2004). This change in the type of vegetation slightly enhanced soil activity 297 that resulted in the negative peak on the $\delta^{13} \mathrm{C}$ values at around $112 \mathrm{ka}$. Finally, the growth of the 298 stalagmite continues up to $105 \mathrm{ka}$ until the hiatus, albeit with slightly lower $\delta^{13} \mathrm{C}$ values (relative 299 to the $112 \mathrm{ka}$ peak), suggesting that the are is still experiencing a period with low soil activity. The $300 \quad \delta^{18} \mathrm{O}$ record during this growth interval up to the growth hiatus shows low variability and is similar 301 to other records from central Europe (Kern et al., 2019). 


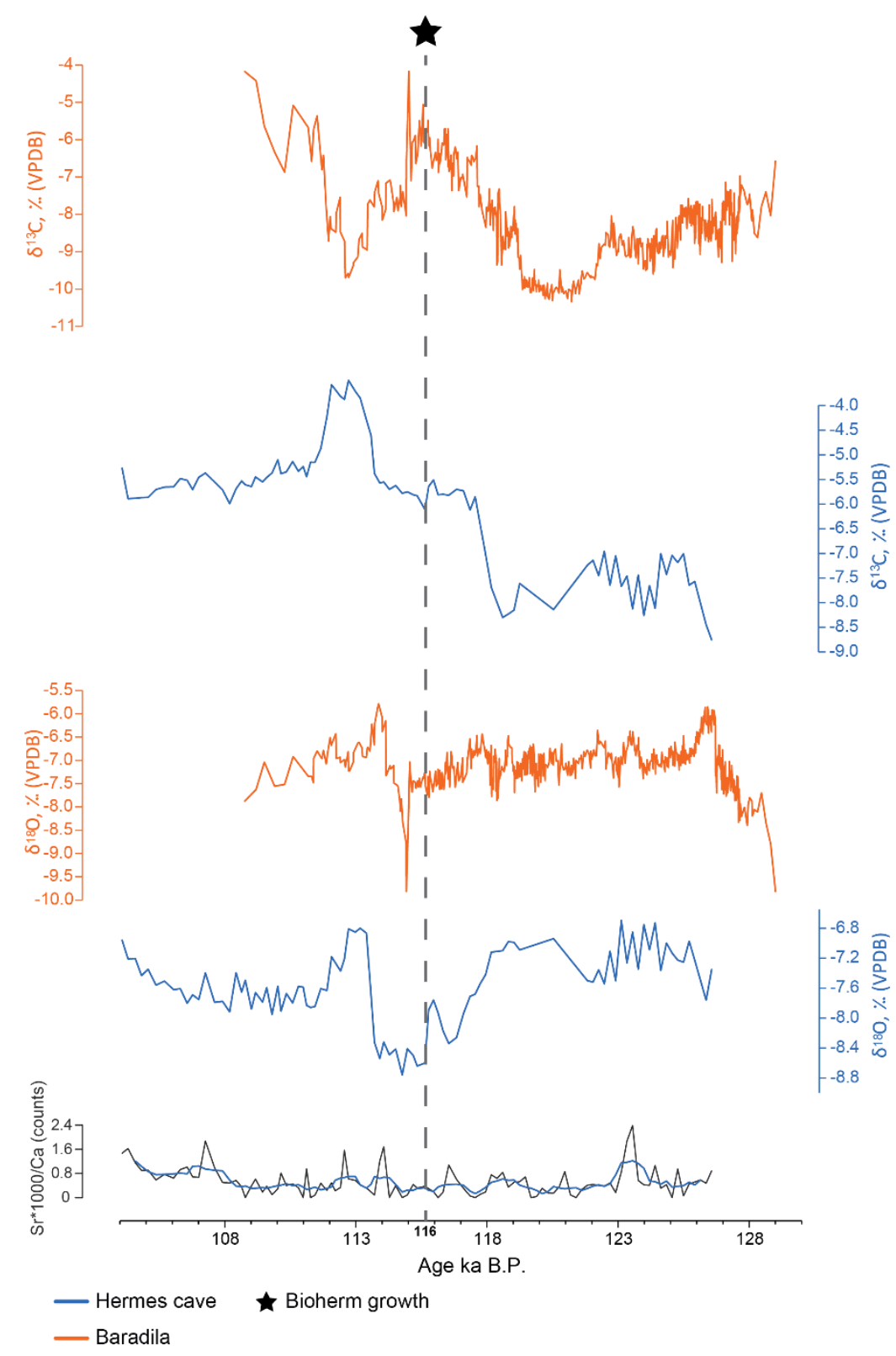

Figure 7. Comparison of ZCG1 last interglacial part with Baradla cave record (Demeny et al., 2017) and bioherm growth (Portman et al., 2005). Although the stalagmite growth hiatus might have occurred for different reasons we suggest that 307 this was the result of low amounts of water infiltrating into the cave and can be attributed to the 
existence of small glaciers that occurred in the area and their expansion during the glacial period (Leontaritis et al., 2020). As warm and humid conditions are generally viewed as prerequisites for speleothem growth (Dreybrodt, 1988; Baker and Smart, 1995; Genty et al., 2006; Nehme et al., 2020), inferences about climate can potentially be made from the prescence of speleothem growth hiatuses. Speleothem growth interruptions may also be due to a change in the fluid pathways reaching the cave; while this cannot be ruled out, the fact that ZCG1 recovered and grew throughout the Holocene makes this option less likely. The ZCG1 hiatus ( 105 to 23 ka B.P; Fig. 3) spans approximately MIS4 to the LGM. MIS3 and MIS4 are thought to generally have been wetter and colder in the Eastern Mediterranean (Bar-Matthews et al., 2003, 2019), indicating conditions more suited to the development of alpine glaciers compared to the warmer temperatures of the preceeding climate phases. In particular, the Eemian (MIS5e) is estimated at $9-11^{\circ} \mathrm{C}$ warmer in the east Mediterranean (e.g. Nehme et al., 2020); temperatures this much higher which would have driven the snowline to a much higher altitude compared to the cooler conditions of later glacial/interglacial cycles. These conditions may have extended to the LGM (Styllas et al., 2015; 2018; Leontaritis et al., 2020 and references within), until at the LGM termination, the temperature and precipitation regime no longer fulfilled the requirements for glacier preservation. After local glaciers either shrank or disappeared, water was able to once again infiltrate Hermes Cave and ZCG1 growth continued. Glacial deposits from the nearby Mount Chelmos have erratics with emplacement dated throughout MIS 3 and the LGM (Leontaritis et al., 2020).

The post-LGM part of the ZCG1 covers the interval from 18 to $8 \mathrm{ka}$. Our record exhibits higher temporal resolution towards the onset of the Holocene as a result of higher growth rate that is most likely related the increased soil productivity under a warm and wet climate. The $\delta^{18} \mathrm{O}$ record exhibits low variability between 18 and $11 \mathrm{ka}$, after which the values become highly variable on 
331 an overall increasing trend linked to the increase in air temperatures and/or humidity after the onset

332 of the Holocene.

333 The overall trend of the $\delta^{13} \mathrm{C}$ records follows that of similar records from regions with comparable 334 climatic conditions - Turkey (Sofular Cave, Fleitmann et al., 2009 ) and Lebanon (Jeita Cave, 335 Cheng et al. 2015). In all these records including the ZCG1 stalagmite, $\delta^{13} \mathrm{C}$ values peak at around $33617 \mathrm{ka}$ and drop between 14.7 and $11.3 \mathrm{ka}$, resuming an increasing trend after the onset of the 337 Holocene (11.7 ka). Similar to the Jeita record, the Bølling-Allerød (BA) and Younger Dryas (YD) 338 are poorly differentiated in the $\delta^{13} \mathrm{C}$ record, possibly indicating that different process resulted in 339 similarly low $\delta^{13} \mathrm{C}$ : enhanced soil productivity linked to post-glacial forest expansion during the 340 warm BA (Feurdean et al., 2014) and increased precipitation delivered by strengthened westerlies 341 linked to the southward displacement of the polar front during the YD (Lane et al., 2013). It is 342 conceivable that while these moisture tracks reached both Greece and the Levant, possibly also 343 picking up moisture from the Eastern Mediterranean, they did not reach the Black Sea coast in 344 Turkey, thus leading to drier conditions there (as indicated by the high $\delta^{13} \mathrm{C}$ values during the YD 345 in the Sofular record (Fleitmann et al., 2009). Similarly high $\delta^{13} \mathrm{C}$ values were recorded in 346 speleothem P10 in SW Romania (Constantin et al., 2010) at the end of the YD, suggesting dry 347 conditions. Collectively, these observations point towards an important differentiation of climatic 348 conditions between SE Europe and the Eastern Mediterranean region during the YD, with a band 349 of cold and dry climatic conditions stretching from Central Europe across the northernmost Balkan 350 Peninsula towards the northern coast of Turkey, and somewhat wetter conditions in southern 351 Greece and Levant, likely brought about by moisture delivered by southerly displaced westerlies. 
352 The onset of the Holocene is marked by increased variability in the $\delta^{13} \mathrm{C}$ and $\delta^{18} \mathrm{O}$ records, similar

353 to those seen in the Jeita and Sofular records. In Hermes Cave, several warm (recorded by the $354 \delta^{18} \mathrm{O}$ ) and wet (recorded by the $\delta^{13} \mathrm{C}$ ) periods punctuate the early Holocene, broadly centered at 9.5, 9.1 and $8.5 \mathrm{ka} \mathrm{BP}$ (Fig. 8) and their timing correlates within error with a wet period recorded 356 on the alluvial fans formations in Perachora penninsula (Peckover et al., 2019). These warm peaks 357 are coincident with cooling events in the Carpathian Mts, as recorded by the $\delta^{18} \mathrm{O}$ of cave ice 358 (Perșoiu et al., 2017). These cooling periods both in South Greece and in Romania are coincident with high $\mathrm{K}^{+}$values measured in the GISP2 record (Mayewski et al., 1997; 2004), which indicate 360 a stronger than usual Siberian High. The Siberian High is a semipermanent high-pressure cell 361 located over Eurasia which affects European and Asian climate in winter (Cohen et al., 2001). 362 Strengthening of the Siberian High results in atmospheric blocking that leads to cold air advection 363 towards northern and central Europe, warming southern Europe and the Levant with stronger than 364 usual clockwise winds across SE Europe and enhanced cyclogenesis over the Central 365 Mediterranean (Perşoiu et al., 2019). These conditions result in increased precipitation delivered 366 to mainland Greece leading to wet conditions and thus potentially explaining the excursions 367 towards negative $\delta^{13} \mathrm{C}$ excursions in the ZCG1 speleothem. Alternatively, the increase in 368 anticyclonic winds could have increased the fraction of moisture sourced from the Aegean Sea. 369 Thus, the high $\delta^{18} \mathrm{O}$ values of speleothem calcite may have been the result of picked-up moisture 370 from the warmed-up Aegean Sea (e.g. Marino et al., 2009). Speleothem $\delta^{18} \mathrm{O}$ records from 371 Peloponnese show contrasting response to changes in precipitation, with the Kapsia record (Finné 372 et al., 2014) indicating high $\delta^{18} \mathrm{O}$ values associated with dry conditions while the Alepotrypa record 373 (Boyd, 2015) suggest high $\delta^{18} \mathrm{O}$ values are indicators of wet conditions (similar to ZCG1) likely, 374 local infiltration conditions may have an outsized effect on the $\delta^{18} \mathrm{O}$-climate relationship. Winter 
375 climatic conditions in the early Holocene were possibly under the influence of the predominantly

376 negative phase of the NAO (Perşoiu et al., 2017) resulting in weakened westerly circulation that

377 probably allowed the westward expansion of easterly winds.

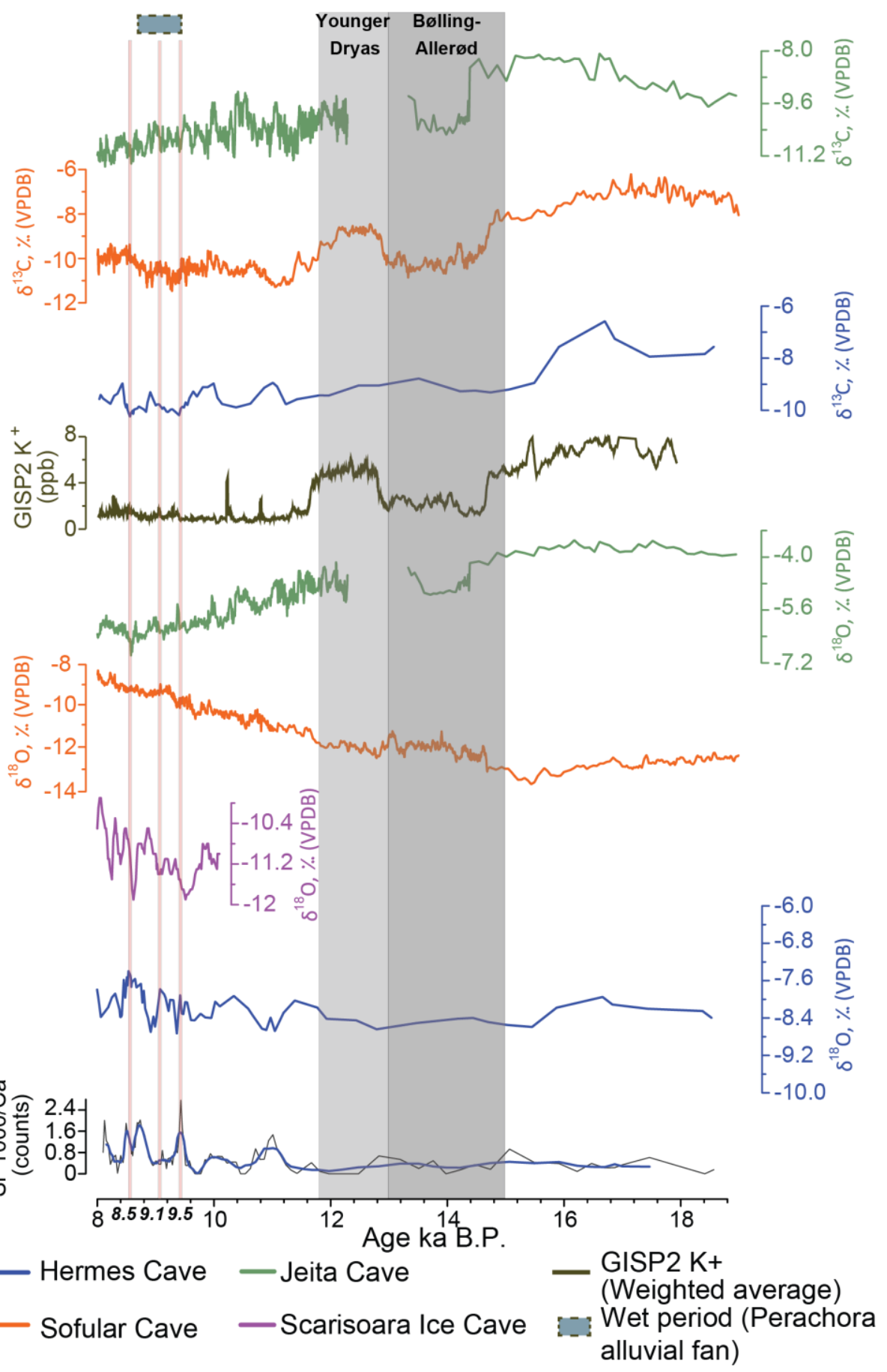


Figure 8. Comparison of ZCG1 post LGM part with other records from the broader area (see text for details).

The $\mu$-XRF results exhibit high variation on the $\mathrm{Sr} / \mathrm{Ca}$ ratio which in combination with the stable isotopes can be used as indicators of seasonal environmental changes. The curve presents a prominent peak at 123-122 ka that correlates with lower values in carbon record and a period of high oxygen values. The $\mathrm{Sr}$ and carbon isotope values suggest wet and warm summers that enhanced soil production in the area but without such warm values or high rainfall amounts that oxygen isotopes were significantly decreased. Again, an increase local, high $\delta^{18} \mathrm{O}$, moisture sources at this time would also help to explain the peristing high oxygen isotope values. The period from $115 \mathrm{ka}$ until the halt in stalagmite growth implies different climatic condition relative to the older part of the stalagmite. In this younger period there are four prominent positive peaks in the curve at ca 114, 112.5, 107and 105 ka that correlate with higher peaks in oxygen and lower peaks in carbon record. This implies that the area was experiencing more precipitation during summer months, but the soil production was low since there is already a transition towards the last glacial period and mean temperature is decreasing. Finally, in the early Holocene section of the stalagmite, we observe four positive peaks in the $\mathrm{Sr} / \mathrm{Ca}$ record centered 9.5, and 8.5 ka that corelate with negative peaks in the carbon record and higher values at the oxygen record that suggest wet conditions during these periods that favored soil formation (Fig.8).

Consequently, for the early Holocene, we suggest that easterly winds driven by a strengthened Siberian High resulted in moisture pick-up from the warm surface waters of the Aegean Sea and subsequent increased precipitation in mainland Greece. 


\subsection{Climatic impact on sediment delivery}

403 Recent results from the IODP Expedition 381 into the Corinth Gulf (Shillington et al., 2019) show

404 a profound variability in sediment accumulation rates in response to climate changes during the

405 Quaternary. In particular, relatively low sedimentation rates $(0.3-0.7 \mathrm{~mm} / \mathrm{yr})$ are infered for the 406 last interglacial period (i.e. MIS 5) in contrast to the higher sedimentation rates that characterize 407 the last glacial ( 2.5 mm/yr) and the Holocene (2.5-3 mm/yr). McNeill et al (2019) argue that the 408 observed variability in sediment flux is due to changes in the type of vegetation cover, while the 409 increased sedimentation rates during the Holocene are attributed to human deforestation in the area 410 from $6000 \mathrm{yr}$ onward. Our results from the lower part of the ZCG1 stalagmite that suggest high 411 soil productivity indicative of an extended vegetation coverage in the area during the oldest parts 412 of MIS 5. During this period, erosion rates were likely depleted by vegetation and fluvial network 413 delivered less sediment into the Gulf of Corinth. Towards the demise of peak (penultimate) 414 interglacial conditions, our data show a decline in soil productivity inferred by higher values of $415{ }^{13} \delta \mathrm{C}$. This is consistent with the results from other studies that imply the development of a weak 416 vegetation cover in the Balkan peninsula (e.g. Tzedakis et al., 2004). Although the stalagmite 417 growth halts during the last glacial period possibly due to shortage of water infiltrating Hermes 418 Cave as a result of the expansion of high altitude small glaciers, at lower elevations there was 419 probably an abundance of meltwater feeding the fluvial network. This combination of weak 420 vegetation cover and high-water supply during the last glacial period drove the high sedimentation 421 rates observed in the Gulf of Corinth (McNeill et al., 2019). The younger part of the stalagmite 422 (post the growth hiatus) suggests a warmer and wetter period. During this period the vegetation 423 didn't recover from the last glacial period since most of the soil was eroded away, thus enabling 
424 only low/open vegetation to grow. This, in combination with the icecap/glacier melting resulted in

425 higher erosion rates on the flanks of the Corinth Rift leading to increased sediment accumulation 426 into the gulf during the onset of Holocene.

\section{Conclusions}

429 This study contributes to the paleoclimatic reconstruction of the Eastern Mediterranean over the

430 Quaternary using a speleothem (ZCG1) from the Hermes Cave, which is located at the southern

431 flanks of the Corinth Rift, central Greece. Our particular findings are the following:

432 - The ZCG1 formation started at $\sim 127 \mathrm{ka}$ marking the establishment of climatic conditions 433 that favored the speleothem deposition. This period coincides with the beginning of the 434 maximum interglacial conditions which enabled the high growth rates observed in 435 stalagmites in Europe.

- We show that a low soil productivity period prevailed in the area from 122 to ca $117 \mathrm{ka}$ B.P. implying overall dryer climatic conditions. This is in disagreenment to the wetter climatic conditions observed in central Europe during the so called 'last Interglacial optimum'. Dry conditions settle in the area later on until the begining of MIS4, when the stalagmite stops growing at ca $105 \mathrm{ka}$ B.P.

- The growth hiatus of ZCG1 from 105 to 23 ka B.P. occurred most probably due to low amounts of water infiltrating into the cave since the area was covered by small glaciers that also expanded during the glacial period. 
- Our record exhibits higher temporal resolution towards the onset of the Holocene due to higher growth rate that is attributed to increased soil productivity under warm and wet climatic conditions.

- ZCG1 record presents similaraties with other records in the broader area of the Eastern Mediterranean. Specifically, during the Bølling-Allerød (BA) and Younger Dryas (YD) our data suggest enhanced soil productivity linked to post-glacial forest expansion during the warm BA and increased precipitation delivered by strengthened westerlies due to southward displacement of the polar front during the YD. Our data show a clear differentiation of climatic conditions during the YD between SE Europe and the Eastern Mediterranean region. During the Early Holocene three warm and wet periods at 8.5, 9.4 ka and 10.1 ka respectively mark the overall warming trend. These warm periods resulted when cold air outbursts associated with a strengthened Siberian High were not strong enough to generate cold conditions over mainland Greece, but these clockwise mowing winds likely picked-up moisture from the Aegean Sea and led to higher than usual precipitation over the area.

- Our record shows high variability in soil productivity and precipitation. The combining effect of these two parameters is the controlling factor on catchment averaged erosion rates with implications to sediment delivery into the Gulf of Corinth.

\section{Acknowledgements}

The authors would like to express their gratitude to cavers Yorgos Sotiriadis, Charikleia Gkarlaouni, Christina Gkarlaouni and Nikolaos Kortimanitsis for their invaluable help during our visit in the Hermes Cave. Ephorate of Palaeoanthropology and Speleology of the Hellenic Ministry of Culture is thanked for granting permission to work inside the cave 
(ҮППОА/ГААПК/ЕПГ/ТАЕМГП/87570/59775/1006/40). RG acknowledges the award of the VISTA Professorship from the Norwegian Academy of Science and Letters. SP and some of the analytical work were also funded by the VISTA Professorship award. AP was supported by the Romanian Ministry of Education and Research, CNCS - UEFISCDI, project number PN-III-P4ID-PCE-2020-2723, within PNCDI III. This work was inspired by the conversations we had with late Prof. Patience Cowie, a great colleague and mentor.

\section{References}

Bar-Matthews, M., Ayalon, A., and Kaufman, A. (2000). Timing and hydrological conditions of Sapropel events in the Eastern Mediterranean, as evident from speleothems, Soreq cave, Israel. Chemical Geology 169(1-2), 145-156. doi: Doi 10.1016/S0009-2541(99)00232-6.

Bourdon, B. (2003). Introduction to U-series Geochemistry. Reviews in Mineralogy and Geochemistry 52(1), 1-21. doi: 10.2113/0520001.

Boyd, M. (2015). Speleothems from Warm Climates : Holocene Records from the Caribbean and Mediterranean Regions. Doctoral thesis, comprehensive summary, Department of Physical Geography, Stockholm University.

Cheng, H., Sinha, A., Verheyden, S., Nader, F.H., Li, X.L., Zhang, P.Z., et al. (2015). The climate variability in northern Levant over the past 20,000 years. Geophysical Research Letters 42(20), 8641-8650. doi: 10.1002/2015g1065397.

Constantin, S., Bojar, A.-V., Lauritzen, S.-E., and Lundberg, J.: Holocene and Late Pleistocene climate in the sub-Mediterranean continental environment: A speleothem record from Poleva Cave (Southern Carpathians, Romania), Palaeogeography, Palaeoclimatology, Palaeoecology, 243, 322-338, https://doi.org/10.1016/j.palaeo.2006.08.001, 2007. 
Coplen, T.B., Brand, W.A., Gehre, M., Groning, M., Meijer, H.A., Toman, B., et al. (2006). New guidelines for delta13C measurements. Anal Chem 78(7), 2439-2441. doi: 10.1021/ac052027c.

Cohen, J., Saito, K., and Entekhabi, D.: The role of the Siberian high in northern hemisphere climate variability, Geophys. Res. Lett., 28, 299-302, https://doi.org/10.1029/2000GL011927, 2001

Croudace, I.W., Rindby, A., and Rothwell, R.G. (2006). ITRAX: description and evaluation of a new multi-function X-ray core scanner. Geological Society, London, Special Publications 267(1), 51-63. doi: 10.1144/gsl.Sp.2006.267.01.04.

Dansgaard, W. (1964). Stable isotopes in precipitation. Tellus 16(4), 436-468. doi: 10.1111/j.2153-3490.1964.tb00181.x.

Demény, A., Kern, Z., Czuppon, G., Németh, A., Leél-Őssy, S., Siklósy, Z., et al. (2017). Stable isotope compositions of speleothems from the last interglacial - Spatial patterns of climate fluctuations in Europe. Quaternary Science Reviews 161, 68-80. doi: 10.1016/j.quascirev.2017.02.012.

Drysdale, R.N., Hellstrom, J.C., Zanchetta, G., Fallick, A.E., Sanchez Goni, M.F., Couchoud, I., et al. (2009). Evidence for obliquity forcing of glacial Termination II. Science 325(5947), 1527-1531. doi: 10.1126/science.1170371.

Fairchild, I.J., and Baker, A. (2012). Speleothem science : from process to past environments / Ian J. Fairchild and Andy Baker ; with contributions from Asfawossen Asrat ... [et al.]. Chichester, U.K: Wiley Blackwell. 
Fairchild, I.J., and Treble, P.C. (2009). Trace elements in speleothems as recorders of environmental change. Quaternary Science Reviews 28(5-6), 449-468. doi: 10.1016/j.quascirev.2008.11.007.

Feidas, H., Noulopoulou, C., Makrogiannis, T., and Bora-Senta, E. (2007). Trend analysis of precipitation time series in Greece and their relationship with circulation using surface and satellite data: 1955-2001. Theoretical and Applied Climatology 87(1-4), 155-177. doi: 10.1007/s00704-006-0200-5.

Feurdean, A., Perşoiu, A., Tanţău, I., Stevens, T., Magyari, E. K., Onac, B. P., Marković, S., Andrič, M., Connor, S., Fărcaş, S., Gałka, M., Gaudeny, T., Hoek, W., Kolaczek, P., Kuneš, P., Lamentowicz, M., Marinova, E., Michczyńska, D. J., Perşoiu, I., Płóciennik, M., Słowiński, M., Stancikaite, M., Sumegi, P., Svensson, A., Tămaş, T., Timar, A., Tonkov, S., Toth, M., Veski, S., Willis, K. J., and Zernitskaya, V.: Climate variability and associated vegetation response throughout Central and Eastern Europe (CEE) between 60 and 8 ka, Quaternary Science Reviews, 106, 206-224, https://doi.org/10.1016/j.quascirev.2014.06.003, 2014.

Finné, M., Bar-Matthews, M., Holmgren, K., Sundqvist, H.S., Liakopoulos, I., and Zhang, Q. (2014). Speleothem evidence for late Holocene climate variability and floods in Southern Greece. Quaternary Research 81(2), 213-227. doi: 10.1016/j.yqres.2013.12.009.

Finné, M., Kylander, M., Boyd, M., Sundqvist, H., and Löwemark, L. (2015). Can XRF scanning of speleothems be used as a non-destructive method to identify paleoflood events in caves? International Journal of Speleology 44(1), 17-23. doi: 10.5038/1827-806x.44.1.2.

Fleitmann, D., Cheng, H., Badertscher, S., Edwards, R.L., Mudelsee, M., Göktürk, O.M., et al. (2009). Timing and climatic impact of Greenland interstadials recorded in stalagmites 
from northern Turkey. Geophysical Research Letters 36(19), L19707. doi:

$$
10.1029 / 2009 \mathrm{~g} 1040050 \text {. }
$$

Friedman, I., O'Neil, J., and Cebula, G. (1982). Two New Carbonate Stable-Isotope Standards. Geostandards and Geoanalytical Research 6(1), 11-12. doi: 10.1111/j.1751908X.1982.tb00340.x.

Gawthorpe, R.L., Leeder, M.R., Kranis, H., Skourtsos, E., Andrews, J.E., Henstra, G.A., et al. (2018). Tectono-sedimentary evolution of the Plio-Pleistocene Corinth rift, Greece. Basin Research 30(3), 448-479. doi: 10.1111/bre.12260.

Genty, D., Baker, A., and Vokal, B. (2001). Intra- and inter-annual growth rate of modern stalagmites. Chemical Geology 176(1-4), 191-212. doi: 10.1016/s0009-2541(00)00399-5.

Genty, D., Verheyden, S., and Wainer, K. (2013). Speleothem records over the last interglacial. PAGES news 21(1), 24-25. doi: 10.22498/pages.21.1.24.

Gogou, A., Triantaphyllou, M., Xoplaki, E., Izdebski, A., Parinos, C., Dimiza, M., et al. (2016). Climate variability and socio-environmental changes in the northern Aegean (NE Mediterranean) during the last 1500 years. Quaternary Science Reviews 136, 209-228. doi: 10.1016/j.quascirev.2016.01.009.

Govin, A., Capron, E., Tzedakis, P.C., Verheyden, S., Ghaleb, B., Hillaire-Marcel, C., et al. (2015). Sequence of events from the onset to the demise of the Last Interglacial: Evaluating strengths and limitations of chronologies used in climatic archives. Quaternary Science Reviews 129, 1-36. doi: 10.1016/j.quascirev.2015.09.018.

Hendy, C.H. (1971). The isotopic geochemistry of speleothems-I. The calculation of the effects of different modes of formation on the isotopic composition of speleothems and their 
applicability as palaeoclimatic indicators. Geochimica et Cosmochimica Acta 35(8), 801824. doi: 10.1016/0016-7037(71)90127-x.

Hercman, H., and Pawlak, J. (2012). MOD-AGE: An age-depth model construction algorithm. Quaternary Geochronology 12, 1-10. doi: Doi 10.1016/J.Quageo.2012.05.003.

Hut, G. (1987). "Consultants' group meeting on stable isotope reference samples for geochemical and hydrological investigations", in: Consultants' group meeting on stable isotope reference samples for geochemical and hydrological investigations).

Jones, T.D., Lawson, I.T., Reed, J.M., Wilson, G.P., Leng, M.J., Gierga, M., et al. (2012). Diatom-inferred late Pleistocene and Holocene palaeolimnological changes in the Ioannina basin, northwest Greece. Journal of Paleolimnology 49(2), 185-204. doi: 10.1007/s10933-012-9654-x.

Katrantsiotis, C., Norström, E., Smittenberg, R.H., Finne, M., Weiberg, E., Hättestrand, M., et al. (2019). Climate changes in the Eastern Mediterranean over the last 5000 years and their links to the high-latitude atmospheric patterns and Asian monsoons. Global and Planetary Change 175, 36-51. doi: 10.1016/j.gloplacha.2019.02.001.

Kern, Z., Demény, A., Perşoiu, A., and Hatvani, I.G. (2019). Speleothem Records from the Eastern Part of Europe and Turkey—Discussion on Stable Oxygen and Carbon Isotopes. Quaternary 2(3). doi: 10.3390/quat2030031.

Kluge, T., Münster, T.S., Frank, N., Eiche, E., Mertz-Kraus, R., Scholz, D., et al. doi: 10.5194/cp-2020-47.

Koukousioura, O., Triantaphyllou, M.V., Dimiza, M.D., Pavlopoulos, K., Syrides, G., and Vouvalidis, K. (2012). Benthic foraminiferal evidence and paleoenvironmental evolution 
of Holocene coastal plains in the Aegean Sea (Greece). Quaternary International 261, 105-117. doi: Doi 10.1016/J.Quaint.2011.07.004.

Kouli, K., Gogou, A., Bouloubassi, I., Triantaphyllou, M.V., Ioakim, C., Katsouras, G., et al. (2012). Late postglacial paleoenvironmental change in the northeastern Mediterranean region: Combined palynological and molecular biomarker evidence. Quaternary International 261, 118-127. doi: 10.1016/j.quaint.2011.10.036.

Lane, C. S., Brauer, A., Blockley, S. P. E., and Dulski, P.: Volcanic ash reveals timetransgressive abrupt climate change during the Younger Dryas, Geology, 41, 1251-1254, https://doi.org/10.1130/G34867.1, 2013.

Leontaritis, A.D., Kouli, K., and Pavlopoulos, K. (2020). The glacial history of Greece: a comprehensive review. Mediterranean Geoscience Reviews. doi: 10.1007/s42990-02000021-w.

Lespez, L., Glais, A., Lopez-Saez, J.-A., Le Drezen, Y., Tsirtsoni, Z., Davidson, R., et al. (2017). Middle Holocene rapid environmental changes and human adaptation in Greece. Quaternary Research 85(02), 227-244. doi: 10.1016/j.yqres.2016.02.002.

Lionello, P., Malanotte-Rizzoli, P., Boscolo, R., Alpert, P., Artale, V., Li, L., et al. (2006). "The Mediterranean climate: An overview of the main characteristics and issues," in Mediterranean, eds. P. Lionello, P. Malanotte-Rizzoli \& R. Boscolo. Elsevier), 1-26. Ludwig, K.R. (2003). Isoplot 3.00: A geochronological toolkit for Microsoft Excel. Berkeley Geochronology Center Special Publication 4, 70.

Mamara, A., Anadranistakis, M., Argiriou, A.A., Szentimrey, T., Kovacs, T., Bezes, A., et al. (2017). High resolution air temperature climatology for Greece for the period 1971-2000. Meteorological Applications 24(2), 191-205. doi: 10.1002/met.1617. 
600

601

602

603

604

605

606

607

608

609

610

611

612

613

614

615

616

617

618

619

620

621

622

Marino, G., Rohling, E.J., Sangiorgi, F., Hayes, A., Casford, J.L., Lotter, A.F., et al. (2009). Early and middle Holocene in the Aegean Sea: interplay between high and low latitude climate variability. Quaternary Science Reviews 28(27-28), 3246-3262. doi: 10.1016/j.quascirev.2009.08.011.

Mayewski, P.A., Meeker, L.D., Twickler, M.S., Whitlow, S., Yang, Q., Lyons, W.B., et al. (1997). Major features and forcing of high-latitude northern hemisphere atmospheric circulation using a 110,000-year-long glaciochemical series. Journal of Geophysical Research: Oceans 102(C12), 26345-26366. doi: 10.1029/96jc03365.

Mayewski, P.A., Rohling, E.E., Curt Stager, J., Karlén, W., Maasch, K.A., David Meeker, L., et al. (2004). Holocene climate variability. Quaternary Research 62(3), 243-255. doi: 10.1016/j.yqres.2004.07.001.

McDermott, F. (2004). Palaeo-climate reconstruction from stable isotope variations in speleothems: a review. Quaternary Science Reviews 23(7-8), 901-918. doi: 10.1016/j.quascirev.2003.06.021.

McNeill, L.C., Shillington, D.J., Carter, G.D.O., Everest, J.D., Gawthorpe, R.L., Miller, C., et al. (2019). High-resolution record reveals climate-driven environmental and sedimentary changes in an active rift. Scientific Reports 9(1). doi: 10.1038/s41598-019-40022-w.

Milner, A.M., Müller, U.C., Roucoux, K.H., Collier, R.E.L., Pross, J., Kalaitzidis, S., et al. (2013). Environmental variability during the Last Interglacial: a new high-resolution pollen record from Tenaghi Philippon, Greece. Journal of Quaternary Science 28(2), 113-117. doi: 10.1002/jqs.2617.

Nehme, C., Kluge, T., Verheyden, S., Nader, F., Charalambidou, I., Weissbach, T., et al. (2020). Speleothem record from Pentadactylos cave (Cyprus): new insights into climatic 
variations during MIS 6 and MIS 5 in the Eastern Mediterranean. Quaternary Science Reviews 250. doi: 10.1016/j.quascirev.2020.106663.

Nehme, C., Verheyden, S., Breitenbach, S.F.M., Gillikin, D.P., Verheyden, A., Cheng, H., et al. (2018). Climate dynamics during the penultimate glacial period recorded in a speleothem from Kanaan Cave, Lebanon (central Levant). Quaternary Research 90(1), 10-25. doi: 10.1017/qua.2018.18.

Nehme, C., Verheyden, S., Noble, S.R., Farrant, A.R., Sahy, D., Hellstrom, J., et al. (2015). Reconstruction of MIS 5 climate in the central Levant using a stalagmite from Kanaan Cave, Lebanon. Climate of the Past 11(12), 1785-1799. doi: 10.5194/cp-11-1785-2015.

Peckover, E.N., Andrews, J.E., Leeder, M.R., Rowe, P.J., Marca, A., Sahy, D., et al. (2019). Coupled stalagmite - Alluvial fan response to the 8.2 ka event and early Holocene palaeoclimate change in Greece. Palaeogeography, Palaeoclimatology, Palaeoecology. doi: 10.1016/j.palaeo.2019.109252.

Pennos, C., Pechlivanidou, S., Aidona, E., Bourliva, A., Lauritzen, S.-E., Scholger, R., et al. (2021). Decoding short-term climatic variations from cave sediments over the MidHolocene: Implications for human occupation in the Katarraktes Cave System, Northern Greece. Zeitschrift für Geomorphologie. doi: 10.1127/zfg/2021/0680.

Perșoiu, A., Onac, B. P., Wynn, J. G., Blaauw, M., Ionita, M., and Hansson, M. (2017). Holocene winter climate variability in Central and Eastern Europe. Scientific Reports 7, 1196. doi:10.1038/s41598-017-01397-w.

Perşoiu, A., Ionita, M., and Weiss, H. (2019). Atmospheric blocking induced by the strengthened Siberian High led to drying in west Asia during the 4.2 ka BP event - a hypothesis. Clim. Past 15, 781-793. doi:10.5194/cp-15-781-2019. 
Petrocheilou, A. (1972). Cave of Herme's or Cave of Pan or Cave of Apollo or Killini's hole (in Greek). Annals of Hellenic Speleological Society 11(5-6), 8.

Philandras, C.M., Nastos, P.T., Kapsomenakis, J., Douvis, K.C., Tselioudis, G., and Zerefos, C.S. (2011). Long term precipitation trends and variability within the Mediterranean region. Natural Hazards and Earth System Sciences 11(12), 3235-3250. doi: 10.5194/nhess-11-3235-2011.

Portman, C., Andrews, J.E., Rowe, P.J., Leeder, M.R., and Hoogewerff, J. (2005). Submarinespring controlled calcification and growth of large Rivularia bioherms, Late Pleistocene (MIS 5e), Gulf of Corinth, Greece. Sedimentology 52(3), 441-465. doi: 10.1111/j.13653091.2005.00704.x.

Psomiadis, D., Dotsika, E., Albanakis, K., Ghaleb, B., and Hillaire-Marcel, C. (2018). Speleothem record of climatic changes in the northern Aegean region (Greece) from the Bronze Age to the collapse of the Roman Empire. Palaeogeography, Palaeoclimatology, Palaeoecology 489, 272-283. doi: 10.1016/j.palaeo.2017.10.021.

Psomiadis, D., Dotsika, E., Zisi, N., Pennos, C., Pechlivanidou, S., Albanakis, K., et al. (2009). Geoarchaeological study of Katarraktes cave system (Macedonia, Greece): isotopic evidence for environmental alterations. Geomorphologie-Relief Processus Environnement 15(4), 229-240. doi: 10.4000/geomorphologie.7694.

Regattieri, E., Isola, I., Giovanni Zanchetta, Andrea Tognarelli, John C. Hellstrom, Russell N. Drysdale, et al. (2020). Middle - Holocene climate variability from a stalagmite from Alilica Cave ( Southern Balkans ). Alpine and Mediterranean Quaternary 1(32). doi: 10.26382/AMQ.2019.02. 
Regattieri, E., Zanchetta, G., Isola, I., Bajo, P., Boschi, C., Perchiazzi, N., et al. (2018). A MIS 9/MIS 8 speleothem record of hydrological variability from Macedonia (F.Y.R.O.M.). Global and Planetary Change. doi: 10.1016/j.gloplacha.2018.01.003.

Remoundaki, E., Bourliva, A., Kokkalis, P., Mamouri, R.E., Papayannis, A., Grigoratos, T., et al. (2011). PM10 composition during an intense Saharan dust transport event over Athens (Greece). Sci Total Environ 409(20), 4361-4372. doi: 10.1016/j.scitotenv.2011.06.026

Rohling, E.J., Marino, G., and Grant, K.M. (2015). Mediterranean climate and oceanography, and the periodic development of anoxic events (sapropels). Earth-Science Reviews 143, 62-97. doi: 10.1016/j.earscirev.2015.01.008.

Rohling, E.J., Marino, G., Grant, K.M., Mayewski, P.A., and Weninger, B. (2019). A model for archaeologically relevant Holocene climate impacts in the Aegean-Levantine region (easternmost Mediterranean). Quaternary Science Reviews 208, 38-53. doi: 10.1016/j.quascirev.2019.02.009.

Shillington, D., McNeill, L., Carter, G., and and the Expedition 381 Participants. (2019). Expedition 381 Preliminary Report: Corinth Active Rift Development. International Ocean Discovery Program. doi: https://doi.org/10.14379/iodp.pr.381.2019.

Skourtsos, E., Kranis, H., Zambetakis-Lekkas, A., Gawthorpe, R., and Leeder, M. (2017). Alpine Basement Outcrops at Northern Peloponnesus: Implications for the Early Stages in the Evolution of the Corinth Rift. Bulletin of the Geological Society of Greece 50(1). doi: 10.12681/bgsg. 11714 .

Stichler, W. (1995). "Interlaboratory comparison of new materials for carbon and oxygen isotope ratio measurements". (International Atomic Energy Agency (IAEA)). 
Stuut, J.-B., Smalley, I., and O’Hara-Dhand, K. (2009). Aeolian dust in Europe: African sources and European deposits. Quaternary International 198(1-2), 234-245. doi: 10.1016/j.quaint.2008.10.007.

Styllas, M.N., and Ghilardi, M. (2017). Early- to mid-Holocene paleohydrology in northeast Mediterranean: The detrital record of Aliakmon River in Loudias Lake, Greece. The Holocene 27(10), 1487-1498. doi: 10.1177/0959683617693905.

Styllas, M.N., Schimmelpfennig, I., Benedetti, L., Ghilardi, M., Aumaître, G., Bourlès, D., et al. (2018). Late-glacial and Holocene history of the northeast Mediterranean mountains New insights from in situ -produced $36 \mathrm{Cl}$ - based cosmic ray exposure dating of paleoglacier deposits on Mount Olympus, Greece. Quaternary Science Reviews 193, 244-265. doi: 10.1016/j.quascirev.2018.06.020.

Styllas, M.N., Schimmelpfennig, I., Ghilardi, M., and Benedetti, L. (2015). Geomorphologic and paleoclimatic evidence of Holocene glaciation on Mount Olympus, Greece. The Holocene. doi: 10.1177/0959683615618259

Triantaphyllou, M.V., Gogou, A., Dimiza, M.D., Kostopoulou, S., Parinos, C., Roussakis, G., et al. (2015). Holocene Climatic Optimum centennial-scale paleoceanography in the NE Aegean (Mediterranean Sea). Geo-Marine Letters 36(1), 51-66. doi: 10.1007/s00367015-0426-2.

Triantaphyllou, M.V., Ziveri, P., Gogou, A., Marino, G., Lykousis, V., Bouloubassi, I., et al. (2009). Late Glacial-Holocene climate variability at the south-eastern margin of the Aegean Sea. Marine Geology 266(1-4), 182-197. doi: 10.1016/j.margeo.2009.08.005. 
711 Tzedakis, P.C. (2010). The MIS 11-MIS 1 analogy, southern European vegetation, atmospheric

712

713

714

715

716

717

718

719

720

721

722

723

724

725

726

727

728

729

730

731

732

733

methane and the 'early anthropogenic hypothesis'. Climate of the Past 6(2), 131-144. doi: 10.5194/cp-6-131-2010.

Tzedakis, P.C., Drysdale, R.N., Margari, V., Skinner, L.C., Menviel, L., Rhodes, R.H., et al. (2018). Enhanced climate instability in the North Atlantic and southern Europe during the Last Interglacial. Nat Commun 9(1), 4235. doi: 10.1038/s41467-018-06683-3.

Tzedakis, P.C., Frogley, M.R., and Heaton, T.H.E. (2002). Duration of Last Interglacial Conditions in Northwestern Greece. Quaternary Research 58(1), 53-55. doi: 10.1006/qres.2002.2328.

Tzedakis, P.C., Frogley, M.R., Lawson, I.T., Preece, R.C., Cacho, I., and de Abreu, L. (2004). Ecological thresholds and patterns of millennial-scale climate variability: The response of vegetation in Greece during the last glacial period. Geology 32(2), 109-112. doi: 10.1130/G20118.1.

Tzedakis, P.C., Hooghiemstra, H., and Pälike, H. (2006). The last 1.35 million years at Tenaghi Philippon: revised chronostratigraphy and long-term vegetation trends. Quaternary Science Reviews 25(23-24), 3416-3430. doi: 10.1016/j.quascirev.2006.09.002.

Wong, C.I., Banner, J.L., and Musgrove, M. (2011). Seasonal dripwater Mg/Ca and Sr/Ca variations driven by cave ventilation: Implications for and modeling of speleothem paleoclimate records. Geochimica Et Cosmochimica Acta 75(12), 3514-3529. doi: 10.1016/j.gca.2011.03.025.

Xoplaki, E., Gonzalez-Rouco, J.F., Luterbacher, J., and Wanner, H. (2004). Wet season Mediterranean precipitation variability: influence of large-scale dynamics and trends. Climate Dynamics 23(1), 63-78. doi: 10.1007/s00382-004-0422-0. 
734 Xoplaki, E., Luterbacher, J., Burkard, R., Patrikas, I., and Maheras, P. (2000). Connection 735 between the large-scale $500 \mathrm{hPa}$ geopotential height fields and precipitation over Greece 736 during wintertime. Climate Research 14(2), 129-146. doi: DOI 10.3354/cr014129.

737 Zerefos, C., Repapis, C., Giannakopoulos, C., Kapsomenakis, J., Papanikolaou, D., Papanikolaou, M., et al. (2011). The climate of the Eastern Mediterranean and Greece: past, present and future. The Environmental, Economic and Social Impacts of Climate Change in Greece, 50-58. 